\title{
Implementation of the Single European Code in a Multi-Tissue Bank
}

\author{
Jan Schroeter Tino Schulz Bernard Schroeter Katrin Fleischhauer Axel Pruß \\ University Tissue Bank, Institute of Transfusion Medicine, Charité - Universitätsmedizin Berlin, Berlin, Germany
}

\author{
Keywords \\ Coding · Tissue bank - Quality control - Traceability
}

\section{Summary}

Introduction: The traceability of tissue and cells transplants is important to ensure a high level of safety for the recipients. With the final introduction of the Single European Code (SEC) in April 2017 in the EU a consistent system among all member states became mandatory. Methods: The regulations for the SEC on EU and national level were evaluated. An overview on the different parts of the SEC with detailed explanations is given. Our own experiences with the implementation of the SEC in our multi-tissue bank are reported in addition. Results: The implementation of the SEC in our multi-tissue bank could be successfully realized. However, it revealed a number of difficulties, especially the sterile labeling of certain tissue transplants and the complex update of the existing database. Conclusion: The introduction of the SEC has made a contribution to the safety of recipients of tissue and cells transplants through a system of comprehensive and transparent traceability.

(c) 2017 S. Karger GmbH, Freiburg

\section{Introduction}

The main focus of the activity of tissue banks is on the comprehensive quality assurance in donor selection and testing besides tissue sampling, which is all based on the principles of good professional practice. Basic elements are the standardized assessment of the clinical history of the donor, taking the tissue-specific contraindications into account, the serology and NAT testing for infectious diseases, the sterile tissue procurement, and the sensitive microbio- logical testing. Despite all safety measures, a small risk of transferring diseases or infections with the tissue transplant remains. Therefore, it is mandatory to establish procedures that enable the traceability from patient to donor. This has been ensured by the introduction of a wide range of traceability and look-back procedures across Europe $[1,2]$. A new instrument is the harmonized labeling among the Member States of the European Union using a standardized coding system. Different ways of its implementation, which is required by the EU Directives 2004/23/EC, 2006/17/EC and 2006/86/EC, were discussed by several tissue establishments and accompanied organizations in the past years leading also to the inclusion of ISBT 128, Eurocode, and EUTC as product coding systems into the Single European Code (SEC) logistics [3-6].

The technical requirements for the coding of human tissues and cells have been implemented by the Commission Directive (EU) 2015/565 amending Directive 2006/86/EC, which was published on April 9, 2015 [7]. This 'Coding Directive' defines the mandatory use of the SEC to ensure traceability from the donor to the recipient and vice versa in the Member States or in the EU facilitate. The European Commission has developed an EU coding platform for this purpose (EU Tissue Establishment Compendium) as well as an EU compendium of approved tissue and cell products (https:// webgate.ec.europa.eu/eucoding/). All tissue establishments that carry out permissible activities with tissues, with tissue preparations or with hematopoietic stem cells or stem cell preparations obtained from the peripheral blood or the umbilical cord blood are recorded in the tissue establishment register. That information remains in the compendium for traceability reasons even though a tissue establishment is not active anymore. Approval-relevant data from the institutions must be reported by the EU Member States to that EU compendium. The implementation of the requirements related to the SEC became mandatory by April 29, 2017.

During the implementation of the SEC in our multi-tissue bank many questions were arising. These questions were discussed on the basis of the 'SEC Information for Competent Authorities and Tissue Establishments' and 'SEC Questions \& Answers' provided

\section{KARGER}

() 2017 S. Karger GmbH, Freiburg

Fax +497614520714 
Fig. 1. Structure of the SEC with formatting specifications and an individual SEC example from our tissue bank.

\begin{tabular}{|c|c|c|c|c|c|c|c|}
\hline \multirow{3}{*}{$\begin{array}{c}\text { SEC } \\
\text { structure }\end{array}$} & \multicolumn{3}{|c|}{ Donation Identification Sequence } & \multicolumn{4}{|c|}{ Product Identification Sequence } \\
\hline & \multicolumn{2}{|c|}{ EU Tissue Establishment Code } & \multirow[b]{2}{*}{ Unique Donation Number } & \multicolumn{2}{|c|}{ Product Code } & \multirow[b]{2}{*}{ Split Number } & \multirow[b]{2}{*}{ [xpiry Date } \\
\hline & $\begin{array}{l}\text { ISU country } \\
\text { code }\end{array}$ & $\begin{array}{l}\text { I Issue establish- } \\
\text { ment number }\end{array}$ & & $\begin{array}{c}\text { Product Coding } \\
\text { System } \\
\text { identifier }\end{array}$ & Product number & & \\
\hline $\begin{array}{l}\text { S[C formatting } \\
\text { specifications }\end{array}$ & $\begin{array}{l}2 \text { alphabetic } \\
\text { characters }\end{array}$ & $\begin{array}{c}6 \text { alpha-numeric } \\
\text { characters }\end{array}$ & $\begin{array}{l}13 \text { alpha-numeric } \\
\text { characters }\end{array}$ & $\begin{array}{c}1 \text { alphabetic } \\
\text { character }\end{array}$ & $\begin{array}{l}7 \text { alpha- } \\
\text { numeric } \\
\text { characters }\end{array}$ & $\begin{array}{l}3 \text { alpha- } \\
\text { numeris. } \\
\text { tharacters }\end{array}$ & $\begin{array}{l}\text { 8 numeric } \\
\text { characters } \\
\text { (YMrYMMDD) }\end{array}$ \\
\hline example & DE & 006850 & 1708701017002 & $B$ & 0736004 & 001 & 20220630 \\
\hline
\end{tabular}

by the European Commission (Health and Food Directorate; Directorate $\mathrm{B}$ - health systems, medical products and innovation): (https://ec.europa.eu/health/blood_tissues_organs/tissues/single_ european_code_en).

Those information and explanations helped us to successfully implement the SEC on the basis of our own experiences with coding and labeling of donations and tissue transplants.

\section{Structure and Format of the Single European Code}

The SEC is a unique identifier which has to be applied to tissues and cells distributed in the European Union for human application. The SEC consists of two parts: a donation identification sequence (SEC-DI) and a product identification sequence (SEC-PI) (fig. 1).

\section{SEC-DI}

The SEC-DI is the first part of the SEC. It consists of the EU tissue establishment code and the unique donation number.

The EU tissue establishment code is the unique identifier for accredited, designated, authorized, or licensed tissue establishments by the member states within EU. It consists of an ISO country code and the tissue establishment number which is supplied by and listed in the EU Tissue Establishment Compendium. This compendium is web-based and provides open access for looking up the relevant entries for traceability of registered tissue establishments (https://webgate.ec.europa.eu/eucoding).

The national competent authorities of the Member States are responsible for the registration of tissue establishments to the EU Tissue Establishment Compendium. They also have to take care that those information are kept up to date. Tissue establishments have to contact their responsible competent authority if they think that their information in the EU Tissue Establishment Compendium need to be changed.

In general one EU tissue establishment code should cover all parts and locations of a single tissue establishment which use the same system for allocating the unique donation number. If tissue establishments use different systems for awarding the donation number for different procurement and processing services, they should have different EU tissue establishment codes. Again it is the responsibility of the national competent authorities to clarify that and to be able to make the appropriate registration at the EU Tis- sue Establishment Compendium. Since that aspect was not relevant for the licensing process of a tissue establishment by the competent authority in Germany so far, one can understand that different EU tissue establishment codes are assigned to the same institution. For our multi-tissue bank, 7 different EU tissues establishment codes are listed in the EU Tissue Establishment Compendium for the different tissue processing units (e.g. cornea bank and bone bank) and procurement facilities.

We have decided to use only one of these codes for all SEC coding purposes since the two different systems for assigning the unique donation number (living and postmortem tissue donation) are consistently and clearly linked to the different parts of our tissue bank.

The unique donation number is the unique number attributed to a specific donation of tissues and cells in accordance with the system in place in each Member State for allocating such numbers (i.e., local allocation by the tissue establishment, central allocation by a national body/system, or international allocation in case of ISBT 128 for countries who adopted ISBT 128 as national coding system for tissues and cells). In Germany the tissue establishments themselves are responsible to create a unique donation number. To fulfill the SEC requirements a 13-digit alphanumeric code for the donation is needed. We assign a unique number to every postmortem tissue donation with the following algorithm. The code, which we now also use as SEC unique donation number, starts with the year of the donation (e.g. for 2017 it is 17), followed by 10 , to differentiate postmortem tissue donations within our institution, and a 4 digit running number starting with 0001 . Using that system, we allocate to the first postmortem tissue donor in 2017 the unique donation number 17100001, to the second 17100002 and so on. For building the SEC-DI that number has to be padded by 5 zeros to obtain the 13-digit unique donation number: 0000017100001 . That way we could keep our established system of donation numbers and are able to follow the SEC regulation. We know that other tissue establishments needed to change or to implement a new system of donation number allocation, e.g. when using more than 13 digits.

According to the German regulations, the tissue establishment responsible and licensed for the tissue procurement has to assign the unique donation number even though it is performed by a cooperation partner, e.g. a surgical or orthopedic clinic at a certain hospital. For building the SEC, its EU tissue establishment code has to be used. At our tissue bank this is the case for the different hospitals providing femoral heads as living donations. We have implemented a new system for the identification of such donations. The 
Fig. 2. Algorithm for the allocation of the unique donation number of femoral head donations.

\begin{tabular}{|c|c|c|c|c|c|c|}
\hline \multicolumn{8}{|c|}{ Donation Identification Sequence } \\
\hline \multirow{2}{|c|}{} & \multicolumn{5}{|c|}{ Unique Donation Number } \\
\hline $\begin{array}{c}\text { ISO-country } \\
\text { code } \\
\text { tissue } \\
\text { establish- } \\
\text { ment } \\
\text { number } \\
\text { ZIP code } \\
\text { of the } \\
\text { donor } \\
\text { hospital } \\
\text { hospital } \\
\text { number } \\
\text { (assigned } \\
\text { by our } \\
\text { tissue } \\
\text { bank) }\end{array}$ & spacer & year & $\begin{array}{c}\text { running } \\
\text { number of } \\
\text { femoral } \\
\text { head } \\
\text { donation }\end{array}$ \\
\hline DE & 006850 & 17087 & 01 & 0 & 17 & 002 \\
\hline \multicolumn{70}{|c|}{ DE0068501708701017002 } \\
\hline
\end{tabular}

\begin{tabular}{|c|c|}
\hline$\underset{\text { TTDE006850 }}{||||||||||||||||||||||||||}$ & $\begin{array}{l}\text { SEC: } \\
\text { DE0068501708701017002 } \\
\text { B073600400120220630 }\end{array}$ \\
\hline |||||||||||||||||| & $\begin{array}{l}\text { SEC: } \\
\text { DE0068501708701017002 } \\
B 073600400120220630\end{array}$ \\
\hline 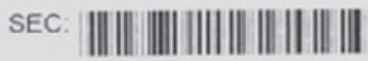 & |||||||| ||||||||||||||| \\
\hline CH-B: 2017070101 & rwendbar bis: 30.06 .2022 \\
\hline
\end{tabular}

Caput femoris, halbiert, 2 Stück, (gt)

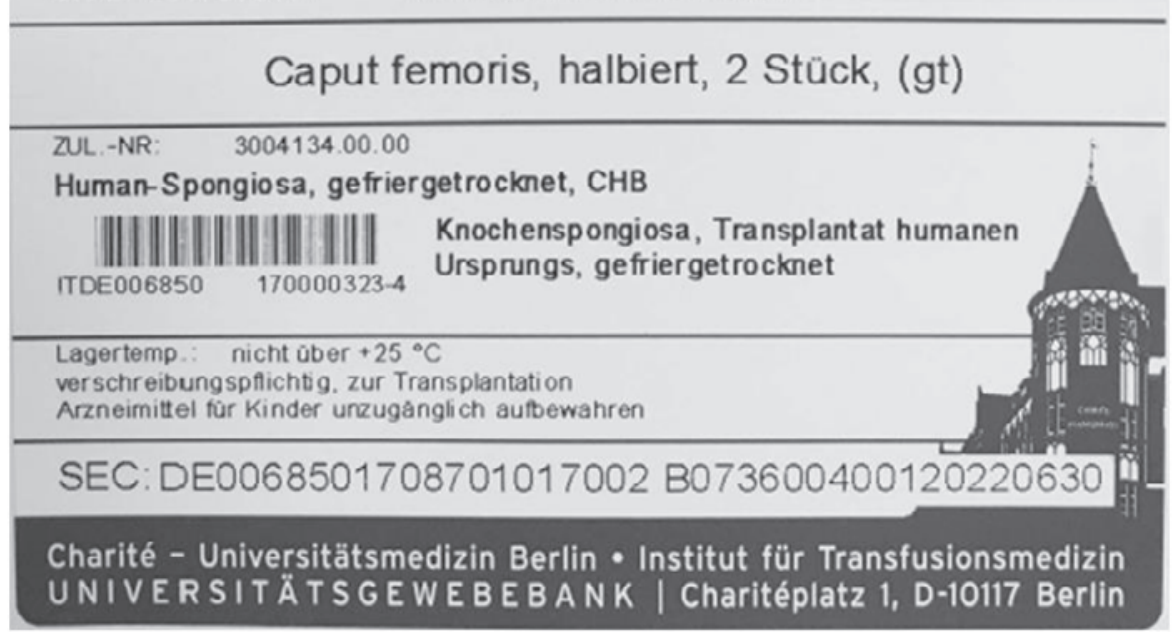

Fig. 3. Label of the outer packaging for half
femoral head with SEC and corresponding barcode.

idea was to include an information about the donor hospital in the unique donation number since the EU tissue establishment code is always our own. With the inclusion of the ZIP code of the donor hospital and an additional hospital number given by our tissue bank we are able to define a donation number which provides both a rapid overview of the different donations at the time of registration in our tissue bank and an improved communication with the donor hospitals which are responsible for the donor approval (fig. 2). The unique donation number generated that way is then included in the Donation Identification Sequence as part of the full SEC and displayed on the final label together with other information, e.g. description and specifications of the tissue transplant (fig. 3). Since the test systems of some laboratories can read only 8 -digit codes we can create a laboratory number by deleting this ZIP code information from those unique donation numbers. That laboratory number is still unique and traceable due to the hospital number. Our existing database was enlarged and is now able to dispatch and process the new donation numbers. That makes it easier and saver to have the SEC-DI as well as the entire SEC on the necessary documentation and labeling.

If tissues or cells from one donation event are sent to different tissue establishments which are responsible for allocating the unique donation number, they should assign the SEC-DI using its own EU tissue establishment code. Otherwise the unique donation number can be the same for all tissues and cells from one donation event if the procurement is performed under the responsibility of a single tissue establishment. When the procurement team of our tissue bank explants ocular, cardiovascular and musculoskeletal tissue from a single donor, the SEC-DI will be the same for all different tissues. It is possible to give the different tissues an additional 
Spendenkennungssequenz (gemäß AMWHV §41b)

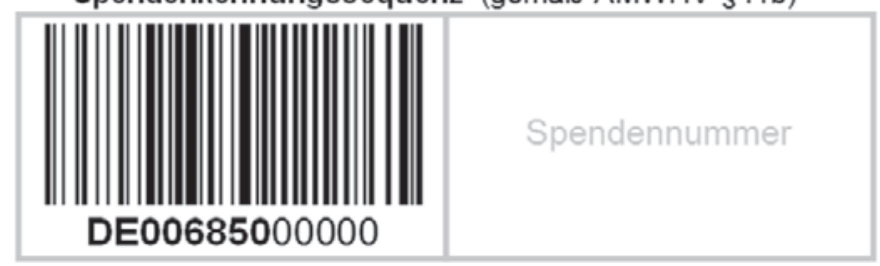

Fig. 4. Part of the recovery report showing the Donation Identification Sequence (Spendenkennungssequenz) with our EU tissue establishment code pre-labeled.

identification number for processing. This identification number, often also specific and traceable to a single donation or donor, can be used besides the SEC even for final labeling of the tissue product. A clear mapping between those existing coding systems and the SEC is necessary, e.g. in the tissue specific documentation within the tissue establishment.

The SEC-DI has to be reported on the tissue recovery report while the explanted tissue has to be labeled at least with the unique donation number. To make the correct documentation for fulfilling the SEC requirements at the time of tissue procurement easier, we have pre-labeled the recovery report with our EU tissue establishment code and the 5 zeros needed for padding our 7-digit unique donation number. That way only our donation number needs then to be added (fig. 4).

Under the regulations of the SEC it is not possible to assign split numbers to differentiate between different tissues from the same donation event within the unique donation number. According to the correspondent EU directives, split numbers should only be used to differentiate between several tissues with the same product code (see SEC-PI section below).

When sending tissues or cells to another tissue establishment for processing, storage or distribution, it will keep its SEC-DI which has to appear unchanged as part of the SEC on the final products.

In those rare circumstances where pooling of tissues and cells is permitted and the donations being pooled already have an allocated SEC-DI or full SEC, a new SEC-DI has to be allocated to the pool. A full traceability of the original codes to the new SEC-DI needs to be maintained in the records.

\section{SEC-PI}

The SEC-PI is the second part of the SEC. It consists of the product code, the split number, and the expiry date (fig. 1). The product code starts with the product coding system identifier indicating which of the three permitted coding systems was used by the tissue establishment ('A' for ISBT 128, 'B' for Eurocode, 'E' for the EUTC). It is followed by the tissues and cells product number, which identifies the specific type of tissue or cell, from the coding system used. Only product numbers listed in the EU Tissue and Cell Product Compendium can be used and incorporated in the SEC (https:// webgate.ec.europa.eu/eucoding/reports/product/index.xhtml).

We have decided to use Eurocode because it is an established and well-working coding system for blood and blood-derived products in Germany for many years.
At present the 3 coding systems available for providing the product number offer quite different options for describing the tissue or cell product. Looking e.g. at corneal transplants, EUTC offers only one number. Eurocode has two numbers making a differentiation between cold and warm storage of the corneal transplant possible. ISBT 128 offers 251 different numbers related to corneal tissue, some of them even for nonexisting tissue preparations. In our opinion, it is important that the product number refers correctly to the type of tissue transplant or cell preparation provided. Specific information about processing and evaluation is already provided in text on the label and the accompanying documents for the user.

The competent authorities are responsible to request a new EUTC code from the European Commission on behalf of the tissue establishment when it is needed for a new tissue or cell product. Eurocode and ISBT 128 will update their product codes regularly for the EU Tissue and Cell Product Compendium following their agreement with the EU. They should be contacted if changes or extensions of existing codes seem to be necessary.

The split number is the number which distinguishes and uniquely identifies tissues and cells having the same unique donation number and the same product code and originating from the same tissue establishment. The split numbers can be defined individually by the tissue establishment. We decided to use running numbers for identical tissue transplants, e.g. cancellous bone. For tissue transplants with a clear limited amount from the same donor we use always the same split number (e.g. 001 for the cornea form the right eye, 002 for the cornea from the left eye).

For tissues or cells distributed in single containers with multiple sub-containers the following regulations apply. If the sub-containers remain together within the primary container up to the point of use, no split number is needed. If, however, the sub-containers might be separated from each other, stored in separately or used in different patients or on different occasions, they should be considered as primary containers, and split numbers should be allocated.

The expiry date is the date by which the tissues and cells can be applied. It has to be expressed in 8 numeric characters starting with the year, followed by month and day (YYYYMMDD). If an expiry date cannot be displayed, e.g. because it is different for the same tissue preparation in a frozen and unfrozen state, 8 zeros should be filled in.

When a tissue establishment receives tissue or cells already given an SEC-DI for processing, storage and distribution, it has to allocate the appropriate SEC-PI and to apply the full SEC.

\section{Application of the Single European Code}

The SEC must be printed on the label of the tissue preparation and has to be recorded in product-related accompanying documents. That way it is ensured that the SEC should remain in the documentation of the tissue or cell transplantation at the recipient. The label must be permanently bonded to the primary packaging of the tissue or cell preparation. If the SEC cannot be placed on the label due to lack of space, it is at least necessary to clearly assign it 
Spongiosa, Chips, 3-7 mm, $15 \mathrm{ccm}$, (gt)

Human-Spongiosa, gefriergetrocknet, $\mathrm{CHB}$

Zul.-Nr. 3004134.00.00 Ch.-B. 2017070601

Verwendbar bis: $\quad 05.07 .2022$

SEC: DE0068500000017100265 B073600200620220705

Charite - Universitătsmedizin Berlin - Institut für Transfusionsmedizin UNIVERSITATSGEWEBEBANK | Chariteplatz 1, D-10117 Berlin

Fig. 5. Label of the inner sterile packaging of human cancellous chips with SEC.

to the accompanying documentation which needs to be packed together with the primary container in a manner that ensures that they remain together.

The SEC must be printed in an eye-readable format (a minimum of 6-point font is recommended) with the SEC-DI and the SEC-PI separated by a single space or as two successive lines preceded by the acronym SEC. Even though there is currently no requirement to provide an additional machine-readable format, the inclusion of a barcode on the label is possible when using a computer-based labeling program (fig. 3).

A particular challenge for the manufacturing process according to the GMP guidelines was the label for the primary sterile inner bag of the double-fold packaging of musculoskeletal transplants. Due to the individual split number the final and specific labeling has to be performed with sterile labels under clean room conditions directly after packaging (fig. 5). With that the labeling of the secondary packing and assembling the accompanying documents with the SEC included also became more challenging, because mismatches are now more likely to happen. We are convinced that the '4-eyes principle' and a double control will work sufficiently.

If a tissue establishment imports tissues or cells for distribution from third countries, it is responsible for the correct application of the SEC.

Within the context of the increasing globalization of the medical world, the safety of substances or products of human origin is of fundamental importance. The introduction of the SEC has made a contribution, in particular, through the resulting comprehensive traceability. The implementation of the SEC in our multi-tissue bank revealed a number of difficulties, especially the sterile labelling of certain tissue transplants and the complex update of the existing database. However, at the end all problems could be sufficiently solved.

In summary, the following steps ensure a correct application of the coding requirements in a tissue establishment:

- Get information on how the legislation has been transposed in your country, in particular which exemptions have been made.

- Obtain your tissue establishment number from the EU Tissue Establishment Compendium or your competent authority.

- Clarify the allocation of the donation identification number, if necessary (individual or national system). Change the system if it is not applicable to the SEC formatting specifications.

- Identify the product coding system from the EU Tissue and Cell Product Compendium you will be using and prepare a reference list for all your tissue or cell products.

- Develop procedures and controls to ensure that each product carries a unique SEC through the assignment of an individual split number to distinguish products carrying the same unique donation number and product code.

- Review and update your label designs and printing systems to accommodate the inclusion of the SEC.

- Update or develop procedures and controls to ensure the correct labeling of the primary packaging, which might be sterile, and the assembly with the accompanying documentation.

\section{Acknowledgment}

The authors would like to thank Mr. Diran Dairani (Double-D-IT) for his support in the technical implementation of the SEC as well as his professional suggestions for implementing a new labeling system.

\section{Disclosure Statement}

The authors declare that they have no conflict of interest in the subject matter of the manuscript and did not receive any financial support.

\section{References}

1 European Commission. Directive 2004/23/EC of the European Parliament and of the Council on setting standards of quality and safety for the donation, procurement, testing, processing, preservation, storage and distribution of human tissues and cells. EUR-Lex. Official Journal of the European Union 2004;102:4858. http://eur-lex.europa.eu/legal-content/EN/TXT/PD $F /$ ? uri $=$ CELEX:32004L0023\&from $=E N$ (last accessed November 6, 2017).

2 European Commission. Directive 2006/86/EC of 24 October 2006 implementing Directive 2004/23/EC of the European Parliament and of the Council as regards traceability requirements, notification of serious adverse reactions and events and certain technical requirements for the coding, processing, preservation, storage and distribution of human tissues and cells. Official Journal of the European Union 2006;294:32-
50. http://eur-lex.europa.eu/legal-content/EN/TXT/PD F/?uri=CELEX:32006L0086 $\sim$ from $=E N$ (last accessed November 6, 2017).

3 Knels R, Mönig HJ, Wittmann G, von Versen R, Pruss A: 'Eurocode International Blood Labeling System' enables unique identification of all biological products from human origin in accordance with the European Directive 2004/23/EC. Cell Tissue Bank. 2010;11:345-352.

4 Distler P, Ashford P, Butch S, Grabowski S, Georgsen J, Muon M: SBT 128 Standard Technical Specification 3.6.0. San Bernardino, ICCBBA, 2009. ISBN: 978-1933243-12-2

5 Mareri M, Filippetti M, Ghirardini A, Vespasiano F, Ciaccio PD, Nanni Costa A: The EUROCET network: support for coding, vigilance and surveillance. Transfus Med Hemother 2011;38:352-356.
6 Fehily D, Costello P, Cresvaux H, Garrido G, Noel L, O’Toole C, Smith M, Swann I, Teskrat F, UhrynowskaTyszkiewicz I, Nanni Costa A: Vigilance and Surveillance of Substances of Human Origin (SOHO V and S) - developing a common approach in the European Union. Blood Transplant Matters 2011;33:20-22.

7 European Commission. Commission Directive EU 2015/565 of 8 April 2015 amending Directive 2006/86/ EC as regards certain technical requirements for the coding of human tissues and cells: Official Journal of the European Union, 2015;L93/43-55. http://eur-lex. europa.eu/legal-content/EN/TXT/PDF/?uri=CELEX:320 15L0565 \&from $=E N$ (last accessed November 6, 2017). 